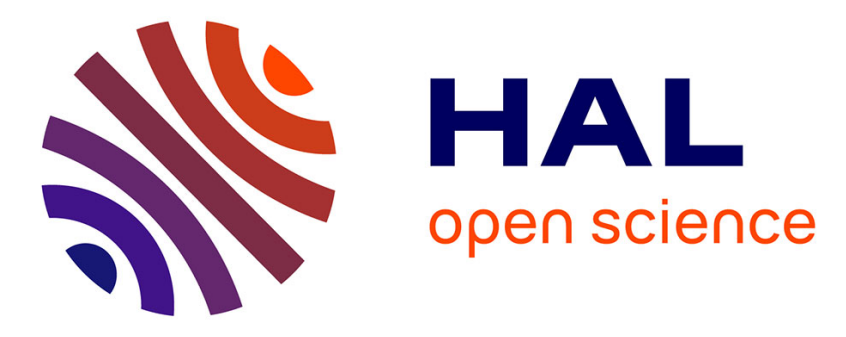

\title{
Monitoring temperature effects on flax cell-wall mechanical properties within a composite material using AFM
}

David Siniscalco, Olivier Arnould, Alain Bourmaud, Antoine Le Duigou, Christophe Baley

\section{To cite this version:}

David Siniscalco, Olivier Arnould, Alain Bourmaud, Antoine Le Duigou, Christophe Baley. Monitoring temperature effects on flax cell-wall mechanical properties within a composite material using AFM. Polymer Testing, 2018, 69, pp.91-99. 10.1016/j.polymertesting.2018.05.009 . hal-01801066

\section{HAL Id: hal-01801066 https://hal.science/hal-01801066}

Submitted on 28 May 2018

HAL is a multi-disciplinary open access archive for the deposit and dissemination of scientific research documents, whether they are published or not. The documents may come from teaching and research institutions in France or abroad, or from public or private research centers.
L'archive ouverte pluridisciplinaire HAL, est destinée au dépôt et à la diffusion de documents scientifiques de niveau recherche, publiés ou non, émanant des établissements d'enseignement et de recherche français ou étrangers, des laboratoires publics ou privés. 
Material Properties

\title{
Monitoring temperature effects on flax cell-wall mechanical properties within a composite material using AFM
}

\author{
David Siniscalco $^{\mathrm{a}}$, Olivier Arnould ${ }^{\mathrm{a}, \mathrm{b}}$, Alain Bourmaud ${ }^{\mathrm{a}, *}$, Antoine Le Duigou ${ }^{\mathrm{a}}$, Christophe Baley

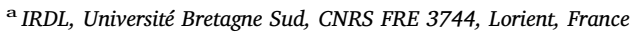 \\ ${ }^{\mathrm{b}}$ LMGC, Université de Montpellier, CNRS UMR 5508, Montpellier, France
}

\section{A B S T R A C T}

PeakForce Quantitative Nano-Mechanical property mapping (PF-QNM) was applied to explore the nano-me-chanical properties of the cell wall of two kinds of flax fibre preparation: isolated and within a poly-(butylene succinate) (PBS) or maleic anhydride grafted poly-(propylene) (PP-MAPP) matrix in unidirectional flax (UD) composites. Isolated flax fibres were subjected to a thermal cycle of $8 \mathrm{~min}$ from ambient temperature to $250{ }^{\circ} \mathrm{C}$. At the same time, flax fibres in a matrix were subjected to an identical cycle from $140{ }^{\circ} \mathrm{C}$ to $250{ }^{\circ} \mathrm{C}$, depending on the nature of the matrix. At the macroscopic scale, tensile tests on both types of sample preparation showed the same trends in temperature effects on the mechanical properties. At the cell wall scale, although no gradient in the cell-wall indentation modulus was revealed by PF-QNM for isolated fibres, a very slight global loss was observed above $210^{\circ} \mathrm{C}$, in accordance with the literature. This decrease was more pronounced for flax fibres within a matrix due the confinement effect of the polymer matrix which isolates fibres from the external en-vironment during thermal treatment. The evolution of the mechanical behaviour of the cell walls leads to em-brittlement of the UD composite, underlining the importance of time-temperature couple monitoring during the processing of plant fibre composites.

\section{Introduction}

Over the last decade, the development of biobased composite materials has become of major industrial importance. Plant fibres can be used in many industrial products as a substitute for synthetic materials, such as glass fibre, for composite reinforcement [1,2]. In Europe, flax fibres have attracted much attention due to their specific mechanical properties [3], their environmental benefits [4] and moderate cost.

Due to the low degradation temperature of plant cell walls [2,5], matrix selection is a crucial parameter in maintaining good fibre properties. Excessively high temperatures $\left(>170{ }^{\circ} \mathrm{C}\right.$ ), or aggressive processes [2] lead to a modification [6] or alteration of the plant cell wall structure and mechanical properties [7-9]. Multiscale analysis should be applied to quantify the changes in behaviour and damage mechanism due to high temperatures. At the nanoscale, nanoindentation is widely used for the characterization of plant cell wall mechanical properties [10]. For example, Li et al. [11], studied the micro-mechanical properties of bamboo using thermal treatments to establish a relation between indentation modulus and hardness with increasing temperature. Zickler et al. [12] studied the behaviour of pyrolysed spruce wood as a function of very high temperature up to $2400^{\circ} \mathrm{C}$, and described different variations depending on the temperature range. Stanszl-Tschegg et al. [13] compared three samples (one reference, $160^{\circ} \mathrm{C}$ and $220^{\circ} \mathrm{C}$ ) of beech wood by nanoindentation, showing a slight increase of the indentation modulus with temperature as well as a significant increase of the hardness. This increase of hardness is generally explained by a cross linking reaction of lignin and xylan at high temperatures [14].

Most previous studies focus on the effect of thermal treatment on isolated fibres, but it remains to establish whether this effect applies to fibres inside a composite during its processing. Moreover, it is difficult to establish a correlation between the properties of fibres and those of the composite because this depends mainly on the matrix and fibres properties but also on the individualization of the latter (i.e., the fact that each fibre is well surrounded by the matrix and is not in contact with other fibres) and the composite material microstructure (including the interface between fibres and matrix). In fact, UD properties are improved if there is a high level of separation of fibres, which is the case for samples with homogeneous isolated fibres and material microstructures [15].

With the development of atomic force microscopy (AFM), new tools have become available to access mechanical properties at the

\footnotetext{
* Corresponding author

E-mail addresses: david.siniscalco@univ-ubs.fr (D. Siniscalco), alain.bourmaud@univ-ubs.fr (A. Bourmaud).
} 
submicron scale inside composite laminates. Nowadays, different techniques based on AFM exist to measure mechanical properties (i.e., indentation modulus that results from the contact stiffness between the AFM tip and the sample surface). PeakForce Quantitative NanoMechanical equipment (PF-QNM) provides force-displacement curves at relatively high frequencies (i.e., a few $\mathrm{kHz}$ ) of each point during topographic imaging [16]. Different parameters such as the indentation modulus or adhesion force can be obtained at the same time at nanoscale resolution. This AFM mode has already been used for plant fibres such as bamboo or flax [17] [18].

The aim of the present study is to investigate the effect of thermal cycle treatment on the mechanical properties of flax cell walls, both on (single) isolated fibres and within a composite laminate. First, PF-QNM was used to measure the evolution of indentation modulus in thermally treated fibres. The PF-QNM approach was chosen due to its better spatial resolution compared to nanoindentation, which allows access to local mechanical gradients. Finally, the same approach was applied to flax fibres within a thermoplastic composite to compare the trends observed in flax fibres with the macroscopic tensile performances of composite materials.

\section{Materials and methods}

\subsection{Isolated fibre thermal treatments}

Technical flax fibres were obtained from flax plants, Marylin variety (2003), cultivated at Le Neubourg (Normandy, France) with a seeding density of 1800 plants $/ \mathrm{m}^{2}$, which corresponds to the conventional density for flax culture [19]. The stems were pulled and submitted to dew-retting for about six weeks until the harvest. Then, they were scutched and hackled by the company Coopérative de Teillage de Lin du Plateau du Neubourg (CTLN, Le Neubourg, Normandy, France).

A Volca (v50e, Prolabo) muffle furnace was used and thermal cycles were run in an air atmosphere at $140{ }^{\circ} \mathrm{C}, 190{ }^{\circ} \mathrm{C}, 210{ }^{\circ} \mathrm{C}$ and $250{ }^{\circ} \mathrm{C}$ for $8 \mathrm{~min}$, which corresponds to a conventional thermoplastic composite process time. This time is really shorter than others found in literature but corresponds for us to a precise time of processing during which fibres undergo heating.

\subsection{Film polymer production and composite laminate preparation}

Biocomposite materials were manufactured with two different polymer matrixes, PP-MAPP and PBS. They were chosen according to their melting temperature, $114.5^{\circ} \mathrm{C}$ [20] and $163.5^{\circ} \mathrm{C}$ [21], respectively, as well as to their good thermal stability. Thus, no degradation of PP (which is the main component of PP-MAPP) is observed up to $250{ }^{\circ} \mathrm{C}$, but occurs in the range from $300^{\circ} \mathrm{C}$ to $500^{\circ} \mathrm{C}$ [22]. For PBS, results of the literature indicate no significant degradation before $200{ }^{\circ} \mathrm{C}$ [23]. The poly-(butylene succinate) (PBS), poly-(propylene) and maleic anhydride grafted polypropylene (PP-MAPP) used in this study were PBS Bionolle 1020 MD (Showa Denko, Tokyo, Japan), OREVAC CA 100 (Arkema) and PP 10642 (Total Petrochemical) grafted with maleic anhydride, respectively.

Cast film extrusion was performed with a Brabender (Germany) single-screw extruder at $40 \mathrm{rpm}$ for PBS and PP-MAPP, using the following temperature profile: $130 / 135 / 140$ in the barrel and $140{ }^{\circ} \mathrm{C}$ and in the nozzle or $190 / 190 / 190$ and $190^{\circ} \mathrm{C}$ for PBS and PP-MAPP, respectively. Unidirectional flax (UD) was made from Lineo ${ }^{\circ}$ FlaxTape $\left(200 \mathrm{~g} \mathrm{~m}^{-2}\right)$. The supplier claims that no treatment (chemical or physical) was performed on these fibres. PBS was used to make composite plates of Flaxtape/polymer at $140^{\circ} \mathrm{C}$, while PP-MAPP was used for the other temperatures $\left(190^{\circ} \mathrm{C}, 210^{\circ} \mathrm{C}\right.$ and $\left.250^{\circ} \mathrm{C}\right)$.

Unidirectional flax composites were manufactured by film stacking [24-26] using a Labtech $^{\odot}$ 50T (USA) moulding press with a $25 \times 25 \mathrm{~cm}^{2}$ heating plate. A total of eight unidirectional flax tape layers were stacked on top of each other to obtain samples without interleaved PP-MAPP or PBS films. This assembly was placed between two aluminium cover plates, which were then inserted into the moulding press. The press was preheated for $1.5 \mathrm{~min}$, and the composite assembly was maintained for $1.5 \mathrm{~min}$ at this temperature at 20 bars: then, a pressure of 35 bar was applied after 3 successive 1-min steps at intervals of 5 bars and a final step held for $2 \mathrm{~min}$ at 35 bars. Thus, the duration of the total hot cycle was $8 \mathrm{~min}$. After the dwell time, the assembly was cooled to $30^{\circ} \mathrm{C}$ in $3 \mathrm{~min}$. The fibre volume fraction varied from $55 \%$ to $60 \%$. Then, $250 \mathrm{~mm} \times 15 \mathrm{~mm} \times 2 \mathrm{~mm}$ samples were cut by milling for tensile characterization.

\subsection{Tensile properties of polymer matrix and composites}

Static tensile tests were carried out using a universal MTS type tensile testing machine equipped with a $10 \mathrm{kN}$ capacity load cell. All the tests were performed at laboratory conditions of $23{ }^{\circ} \mathrm{C}$ and $48 \%$ relative humidity. The crosshead speed was $1 \mathrm{~mm} / \mathrm{min}$ for composites and $50 \mathrm{~mm} / \mathrm{min}$ for pure polymers. An extensometer was used with a nominal gauge length of $25 \mathrm{~mm}$ for the composite tensile tests. Tests were carried out at least five times for each specimen and results were averaged. All tests on composites were carried out in the direction of the fibre axis. The Young's modulus of polymers and composites was calculated from the initial segment of the stress/strain curve (i.e., corresponding to a longitudinal strain between 0.025 and $0.1 \%$ ).

\subsection{Sample preparation for PF-QNM analysis}

Both isolated fibres and UD composites had to be prepared before AFM mechanical testing as their measured cross-section surface should be as flat as possible at the nanometre scale to ensure reliable results.

Thermally treated fibres were dehydrated with a concentration series of ethanol/deionised water (50\%, 75\%, 90\% and 100\%) and then embedded in a mixture containing increasing ratios of Agar epoxy (AGAR low viscosity resin kit, AGAR Scientific Ltd., Stansted, UK)/ ethanol (25\%, 50\%, $75 \%$ and $100 \%)$. The flax fibres were embedded to maintain their cell wall structure during the sample surface preparation by microtome. Final embedding resin polymerisation was carried out in an oven $\left(60^{\circ} \mathrm{C}\right.$, overnight).

UD samples were embedded in an epoxy resin (Struers Epofix) to maintain the global composite and fibre structure during preparation of the sample surface by microtome. Final coating resin polymerisation took place at ambient temperature (overnight).

Embedded samples were then machined to reduce their cross section to $1 \times 2 \mathrm{~mm}$, and an ultramicrotome (Leica Ultracut $\mathrm{R}$ ) with diamond knives (Diatom Histo and Ultra AFM) was used to cut a series of very thin sections (about $50 \mathrm{~nm}$ thick in the last step) at reduced cutting speed $(\approx 1 \mathrm{~mm} / \mathrm{s})$ to minimize compression and sample deformation during the cutting process. This preparation method results in much reduced surface roughness, which makes it possible to obtain relevant AFM PF-QNM measurements.

\subsection{AFM PeakForce QNM}

AFM mechanical characterization was performed on both isolated fibres and composite samples, after embedding described above, with a Multimode AFM Instrument (Bruker Corporation, Santa Barbara, USA) using PF-QNM imaging mode, which is an extension of the peak force Tapping ${ }^{\mathrm{TM}}$ mode where the vertical motion of the cantilever oscillates far below its resonant frequency $(2 \mathrm{kHz})$. Each tapping event is an action of the probe indenting into the surface of the sample (typically 1-3 nm). Measurements were carried out using a RTESPA-525 (Bruker) probe with a cantilever spring constant of around $200 \mathrm{~N} / \mathrm{m}$. The probe was calibrated with the so-called Sader method [27] using a Scanning Electron Microscope (Jeol JSM 6460LV) to determine cantilever length and width, and AFM in Tapping ${ }^{\mathrm{TM}}$ mode to record its frequency response (resonance frequency and quality factor). The tip radius, 

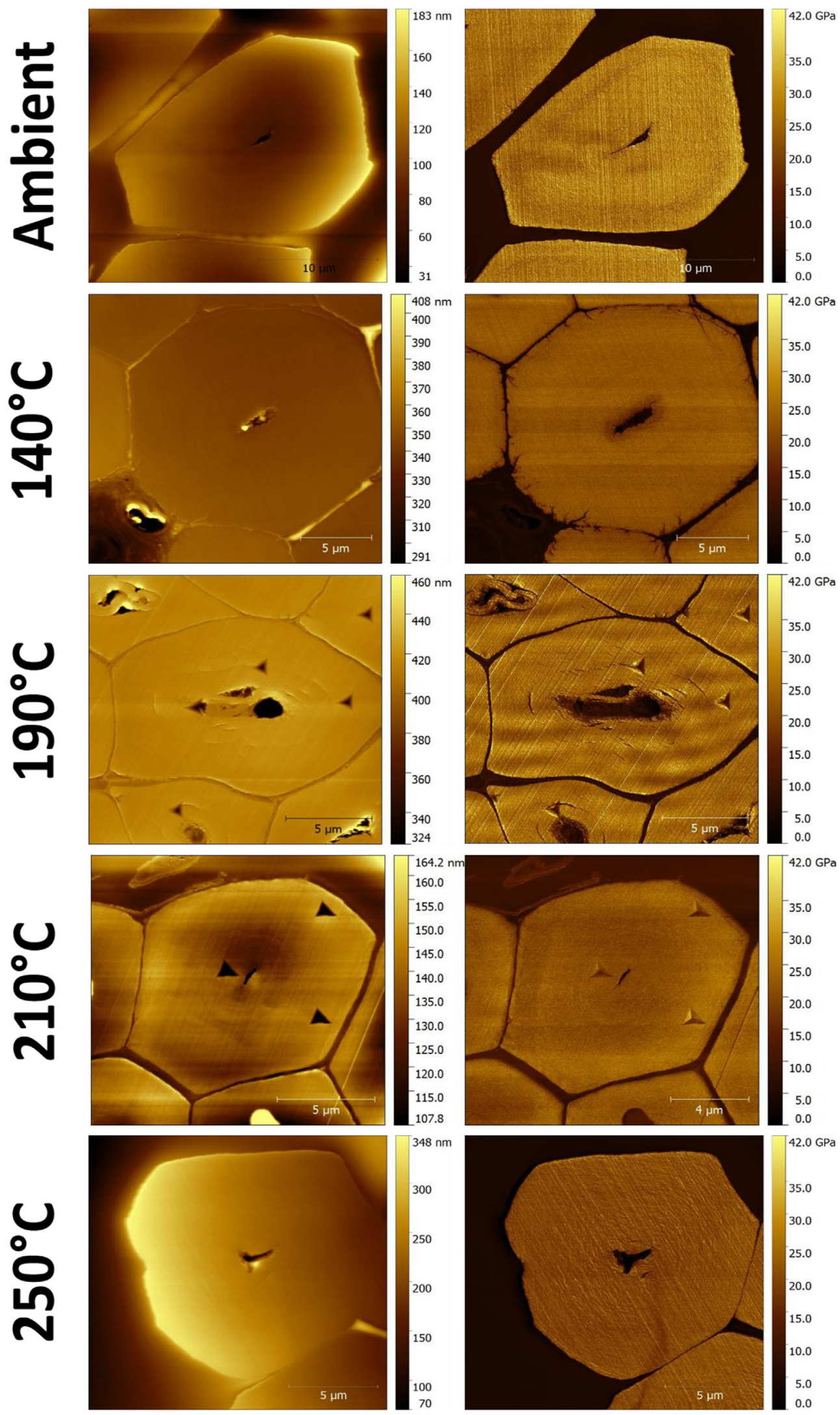

Fig. 1. Topography surface and indentation modulus maps on isolated flax fibres treated at different temperatures (ambient, $140^{\circ} \mathrm{C}, 190^{\circ} \mathrm{C}, 210^{\circ} \mathrm{C}$ and $250^{\circ} \mathrm{C}$ ) by PeakForce-QNM. 
between $9 \mathrm{~nm}$ and $50 \mathrm{~nm}$, was tuned during the measurement on a Highly Oriented Pyrolytic Graphite (HOPG) standard from Bruker so as to obtain an indentation modulus of around $18 \mathrm{GPa}$, while taking the adhesion force into account with a DMT contact model [28]. The applied maximum load (peak force) was set to $200 \mathrm{nN}$ for all the measurements, leading to a contact stiffness of the same order as the cantilever stiffness for the studied materials, and images were obtained at a scan speed of $8 \mu \mathrm{m} / \mathrm{s}$. The calibration was checked by comparing values with the results obtained by nanoindentation, especially in the embedding resin, and measurements on an Aramid fibres/epoxy sample, where indentation moduli between around 5 to more than $20 \mathrm{GPa}$ have been found [20]. Images were analysed with Gwyddion (version 2.39).

\subsection{Nanoindentation}

A commercial nanoindentation (NI) system Nanoindenter XP (MTS Nano Instruments) equipped with a three-side pyramid indenter (Berkovich) was used at room temperature. For all the tested samples, a maximum indentation depth of $150 \mathrm{~nm}$ was used with a loading rate of $0.05 \mathrm{~s}^{-1}$ (i.e., $1 \mu \mathrm{N} / \mathrm{s}$ ), followed by holding the sample at maximum load for $20 \mathrm{~s}$ before unloading at a rate of $10 \mu \mathrm{N} / \mathrm{s}$, after which a final holding segment was carried out for thermal drift assessment and correction. The nanoindentation was used to check the indentation modulus value found by PeakForce-QNM in the fibres and in the matrix or embedding resin on some samples.

\subsection{SEM}

The microstructure of the composite cross-sections and fracture surfaces was analysed by scanning electron microscopy (SEM). The samples were sputter-coated with a thin layer of gold in an Edwards Sputter Coater and analysed with a Jeol JSM 6460LV scanning electron microscope.

\section{Results and discussion}

\subsection{PeakForce QNM on elementary fibres}

To study the evolution of mechanical properties, PF-QNM mapping was used on fibres at different temperatures. Fig. 1 shows the topography and indentation modulus maps of fibre cross-sections (ambient, $140^{\circ} \mathrm{C}, 190^{\circ} \mathrm{C}, 210^{\circ} \mathrm{C}, 250^{\circ} \mathrm{C}$ ). The scale bars are not the same to increase the resolution of each image to the maximum. Each image focuses on a single fibre. Some lines are visible which arise from the surface preparation. On some images, undulations, or waves, can be seen on the indentation modulus maps. This is due to interferences from the AFM laser that sometimes occurs and induces a bias, especially in the measurement of the adhesion force. Note that indentation marks are visible due to the nanoindentation experiments. In this study, nanoindentation was used for sample treated at $190^{\circ} \mathrm{C}$ and $210^{\circ} \mathrm{C}$ to check and validate the indentation modulus values found by AFM, with experiments containing 50 indents for each tested temperature. Indentation modulus of $22.1 \pm 2.4 \mathrm{GPa}(\mathrm{NI})$ and $23.4 \pm 3.2 \mathrm{GPa}$ (PF$\mathrm{QNM})$ or $20.5 \pm 1.4 \mathrm{GPa}(\mathrm{NI})$ and $21.5 \pm 2.5 \mathrm{GPa}(\mathrm{PF}-\mathrm{QNM})$, were found for $190^{\circ} \mathrm{C}$ and $210^{\circ} \mathrm{C}$, respectively. These results confirm the tendency previously shown by Arnould et al. [18], and highlights the relevance and validity of our AFM PF-QNM stiffness measurements.

PF-QNM has been shown to be sensitive to indentation modulus gradients in flax cell wall and aramid fibres [18]. In our case, no gradient is visible on each image of Fig. 1. In fact, no significant changes were visible on the surface, indicating that the flax cell-wall stiffness is quite homogenous whatever the cycle. Using indentation modulus maps, the cell wall stiffness distribution can be analysed using the height distribution function (Gwyddion 2.39) and then fitted by a Gaussian distribution (software OriginPro 2017). On each sample, the distribution is mainly made of two peaks, the highest one (in terms of a)

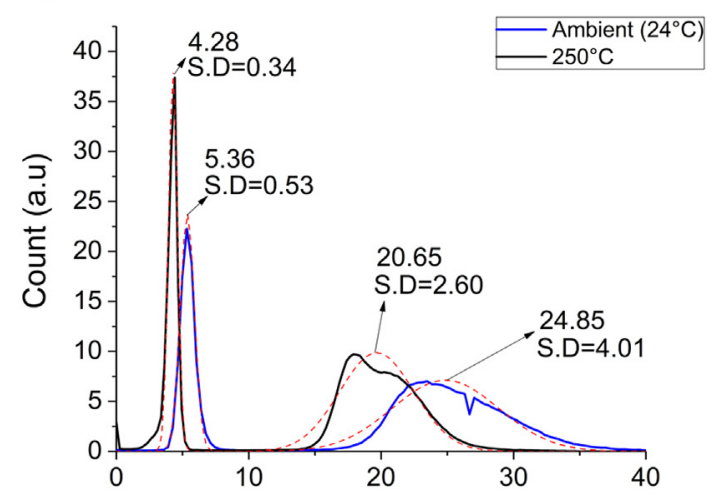

b)

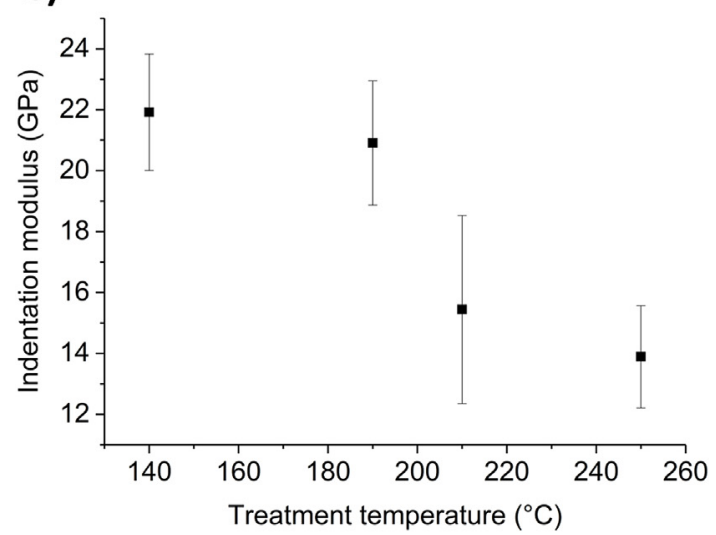

Fig. 2. a) Indentation modulus distribution, from maps in Fig 1 , of embedded isolated flax fibres at ambient $\left(24^{\circ} \mathrm{C}\right)$ and after a thermal treatment at $250{ }^{\circ} \mathrm{C}$, fitted with Gaussian distribution (red dashes). The lowest peaks correspond to the embedding resin whereas the highest ones to the flax cell wall. b) Variation of the mean indentation modulus for isolated flax fibres treated at different temperatures (ambient, $140^{\circ} \mathrm{C}, 190^{\circ} \mathrm{C}, 210^{\circ} \mathrm{C}$ and $250{ }^{\circ} \mathrm{C}$ ) by PeakForce-QNM. (For interpretation of the references to colour in this figure legend, the reader is referred to the Web version of this article.)

indentation modulus) was attributed to the fibres cell wall, the lowest one to the material surrounding the fibres (composite matrix or embedding resin). A Gaussian distribution is adjusted on each peak and gives the mean value (i.e., value at the maximum of the distribution) and the standard deviation (S.D). Fig. 2 a presents an example of the analysis applied on ambient and $250^{\circ} \mathrm{C}$ treated fibres with the distribution of the cell wall indentation modulus (Fig. 2a). The evolution of flax cell-wall mean indentation modulus according to thermal cycle treatment is also shown (Fig. 2b). The scale bar in Fig. 2b has been adjusted to show the slight modification of the indentation modulus. For each point, a minimum of 5 fibres in different regions of each sample have been studied to yield relevant results, taking into account the significant scattering of modulus in flax fibres.

A slight decrease of the indentation modulus, from $24.8 \pm 4.0 \mathrm{GPa}$ to $20.6 \pm 2.6 \mathrm{GPa}$, is observed with increasing temperature. Interestingly, these results confirm the trends observed in tensile tests on single fibres by Bourmaud et al. (2016) [9]. These authors (op. cit.) concluded that a thermal cycle of $8 \mathrm{~min}$ at $210^{\circ} \mathrm{C}$ induces a decrease in fibre stiffness, strength and Young's modulus, which is mainly attributed to major changes in the structure of non-cellulosic polysaccharides (NCP).

Nevertheless, regarding the overall behaviour during a single fibre tensile test, the Young's modulus is stable between room temperature and $140{ }^{\circ} \mathrm{C}$ : this feature is not totally highlighted by PF-QNM. Indeed, although single fibre tensile testing and nanoindentation/AFM allow 


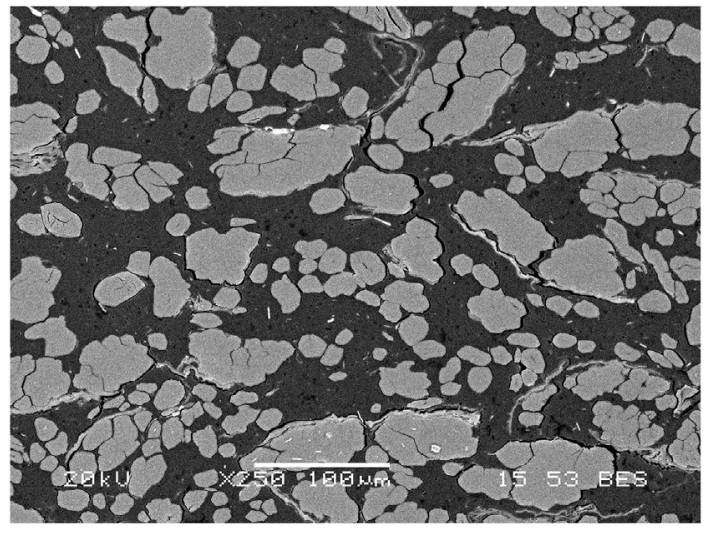

Fig. 3. SEM image of the cross section of PP-MAPP/Flax composite processed at $190^{\circ} \mathrm{C}$.

mechanical characterization, they are applied at different scales and with a different kind of loading. Using tensile experiments, the whole structure of the fibre is characterized and, consequently, the mechanical information represents, not only the whole fibre cell wall behaviour (averaged all along the fibre), but also possible interactions between layers or specific components such as NCP or cellulose microfibrils. Moreover, the loading is purely uniaxial in the fibre axis direction that leads to a global measurement of Young's modulus of the fibre. On the contrary, NI or PF-QNM focuses on the very near surface of a single section of the fibre and measures elastic properties inside the cell wall at the ultrastructural level; hence, the multiaxial loading in indentation leads to measure an indentation modulus. This latter not only depends on the Young's modulus in the fibre axis but also on the transverse Young's moduli and shear moduli [10]. This explains the difference between the cell-wall Young's moduli reported in Fig. 2 and Bourmaud et al. (2016) [9]. Eder et al. [10] report that the indentation modulus is also less sensitive to the microfibril angle (MFA) of the cell layer than the longitudinal Young's modulus measured by single-fibre testing. The effect of the cell-wall matrix on the indentation modulus seems as important as the MFA [12]. The effect of NCP matrix is the most important parameter affecting the tensile behaviour of single flax fibres [7], and can also explain differences in the relative reduction of indentation modulus with increasing temperature treatment, as shown on Fig. 2 and results from Bourmaud et al. [9]. It can be noted that the trend between these two results is nevertheless similar.

Generally speaking, due to the specific nature of plant cell walls, mainly composed of cellulose, pectins and hemicelluloses, the increase of temperature can induce a strong degradation of their mechanical properties. Indeed, Baley et al. [7] show that, after heating for $14 \mathrm{~h}$ at $105^{\circ} \mathrm{C}$, the tensile strength is highly affected and cell wall structure undergoes irreversible damage linked to a decrease of interaction between mesofibrils and pectin. Paris et al. [30] have studied spruce and pine pyrolysis in the temperature range between $25^{\circ} \mathrm{C}$ and $1400{ }^{\circ} \mathrm{C} \cdot \mathrm{In}$ the range between $35^{\circ} \mathrm{C}$ and $250^{\circ} \mathrm{C}$, these authors highlight the evaporation of water and dehydration with slight depolymerisation, but no change of cellulose microfibrils. Between $250^{\circ} \mathrm{C}$ and $350{ }^{\circ} \mathrm{C}$, they observe a degradation of all polymers and a degeneration of the cellulose crystal structure as well as disappearance of the lignin matrix. In addition, Zolfrank and Fromm [31] have studied wood pyrolysis between $200{ }^{\circ} \mathrm{C}$ and $300{ }^{\circ} \mathrm{C}$. In the range of $200^{\circ} \mathrm{C}-250^{\circ} \mathrm{C}$, they demonstrate at first a degradation of polyoses and a disorientation of cellulose microfibrils away from the fibre axis; near $250{ }^{\circ} \mathrm{C}$, there is a decomposition of microfibrils associated with poorer cellulose orientation.

\subsection{PeakForce QNM on UD composites}

The microstructure and volume fraction of composites can be analysed from the SEM images, such as shown in Fig. 3. Fibre volume was determined by using SEM images at different temperatures with the software Image $J$. A threshold was applied to mask fibres on the image. The porosity was calculated as the difference between the total image surface and the fibre surfaces, then converted to percentage. Fibre
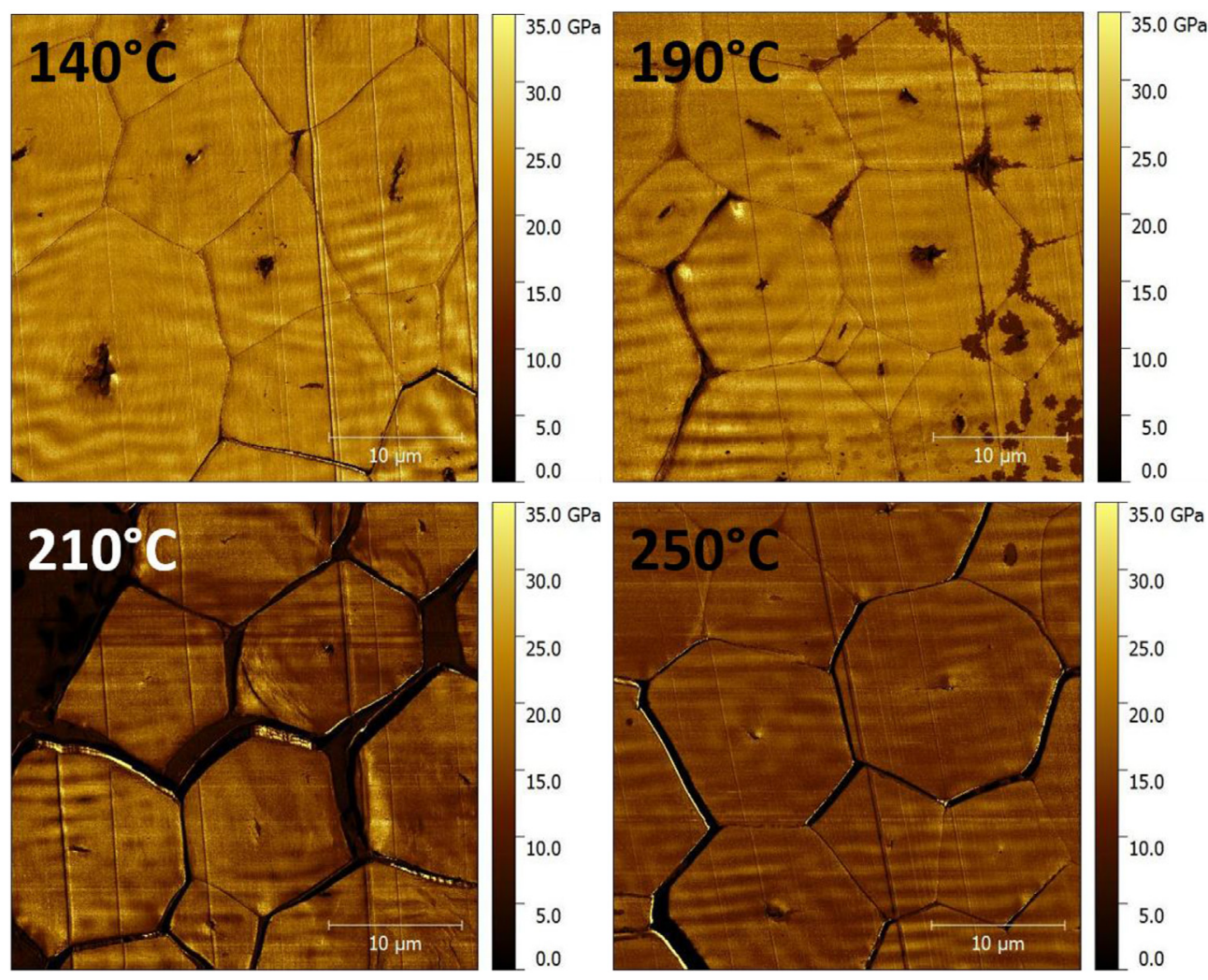

Fig. 4. PeakForce-QNM indentation modulus maps of composite polymer/flax fibres processed at different temperatures $\left(140^{\circ} \mathrm{C}, 190^{\circ} \mathrm{C}, 210^{\circ} \mathrm{C}\right.$ and $\left.250^{\circ} \mathrm{C}\right)$. 
volume fractions are found to be $56 \%$ for PBS/Flax at $140{ }^{\circ} \mathrm{C}, 55 \%$ for PP-MAPP/Flax at $190^{\circ} \mathrm{C}, 59 \%$ for PP-MAPP/Flax at $210^{\circ} \mathrm{C}$ and $57 \%$ for PP-MAPP/Flax at $250^{\circ} \mathrm{C}$. The porosity is around $4 \%$, which ensures the quality of each sample. No significant difference is noted in the microstructure and quality of the different samples.

Fig. $4 \mathrm{a}$ and $\mathrm{b}$ presents some indentation modulus distribution $\left(140^{\circ} \mathrm{C}\right.$ and $\left.250^{\circ}\right)$ and indentation modulus maps of composite samples (polymer/flax fibres) obtained using PeakForce-QNM. For each composite, a large area of $35 \times 35 \mu \mathrm{m}^{2}$ is covered, including at least 10 fibres that were taken to be representative of the sample. 5 different areas of each sample were analysed. The same method as used for isolated fibres was applied here to analyse the images and calculate the mean indentation modulus and standard deviation. On Fig. 4a, two examples of this analyse are shown to clarify the procedure and show differences between $140{ }^{\circ} \mathrm{C}$ and $250{ }^{\circ} \mathrm{C}$. As previously observed on isolated fibres, no indentation modulus gradient can be seen on Fig. 4b.

Fig. 5 shows the evolution of the indentation modulus versus the process temperature of composites. A drastic fall of this indentation modulus is highlighted at high temperatures. This indentation modulus
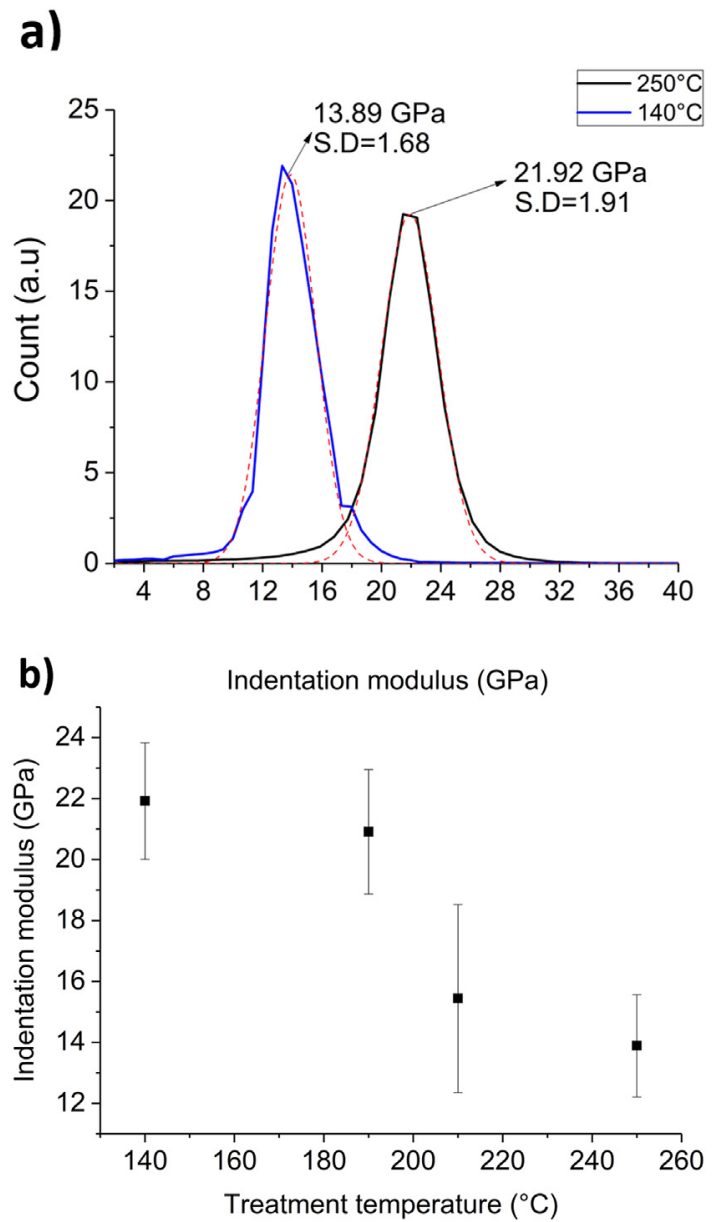

Fig. 5. a) Indentation modulus distribution, from maps in Fig 4, of flax fibres cell wall within composites processed at $140{ }^{\circ} \mathrm{C}$ and $250{ }^{\circ} \mathrm{C}$ with a Gaussian fit (red dashes). Peaks corresponding to the polymer matrix are not shown. b) Variation of the indentation modulus of the flax fibres cell wall within composites processed at different temperatures $\left(140{ }^{\circ} \mathrm{C}, 190{ }^{\circ} \mathrm{C}, 210^{\circ} \mathrm{C}\right.$ and $\left.250{ }^{\circ} \mathrm{C}\right)$, measured by PeakForce-QNM. (For interpretation of the references to colour in this figure legend, the reader is referred to the Web version of this article.) is stable until $190^{\circ} \mathrm{C}$ at around $21 \mathrm{GPa}$, but a change occurs at $210^{\circ} \mathrm{C}$ with a pronounced decrease from 21 to $16 \mathrm{GPa}$. At $250{ }^{\circ} \mathrm{C}$, this indentation modulus is close to $14 \mathrm{GPa}$. These results indicate that a high temperature cycle in a polymer matrix induces a marked degradation of fibre mechanical properties (i.e., Young's modulus). In fact, isolated fibres studied at the same process temperature undergo a quite slight change in indentation modulus (Fig. 2). Here, the use of a matrix induces a drastic loss of indentation modulus. Comparing Figs. 2 and 5 where the same process temperatures are applied, we can see a drastic decrease of the indentation modulus associated with the presence of a matrix compared to isolated fibres (difference of decrease of 30\%-40\% between an isolated fibre and fibres within a composite material after $210^{\circ} \mathrm{C}$ and $250{ }^{\circ} \mathrm{C}$ of treatment cycle).

To explain this phenomenon, we should point out that the manufacturing method is not the same for elementary fibres and composites. Single fibres are dehydrated using ethanol before embedding and reequilibrate with the environmental condition after cutting with the microtome, which is not the case for composite fibres; in this latter material, dehydration can potentially occur during the thermo-compression phase. It is well known that the moisture content has an important effect on the mechanical properties. Baley et al. [32] showed that drying flax fibres significantly influences their behaviour, and especially the tensile strength, because the loss of water involves a modification of adhesion between cellulose microfibrils and matrix, creating or damaging the chemical bonds. These authors (op. cit.) demonstrated an evolution of the components ensuring a load transfer between the microfibrils, thus conditioning the strength of the cell walls. These changes were not only observed in flax fibres but also in wood, and have also been highlighted by Brandt et al. [33] and Stamboulis et al. [34] who show that a process treatment induces a variation of adsorbed moisture, which impacts the tensile strength properties of fibres.

The difference between elementary fibres and fibres included in composite can be explained by the presence of confined water in interfacial areas between matrix and fibres. This could induce accelerated deterioration of flax cell walls due to an increase in pressure associated with water evaporation; the additional pressure can be an aggravating factor contributing to decohesion of the flax cell wall. Moreover, the compression process leads to non-negligible additional mechanical damage due to the pressure shear stress. Typically, the film stacking process generates a shear rate of around $10 \mathrm{~s}^{-1}$ [35]. In addition, radial compression, linked to the thermo-hygroscopic residual stress, can occur during the cooling, which enhances the damage effect.

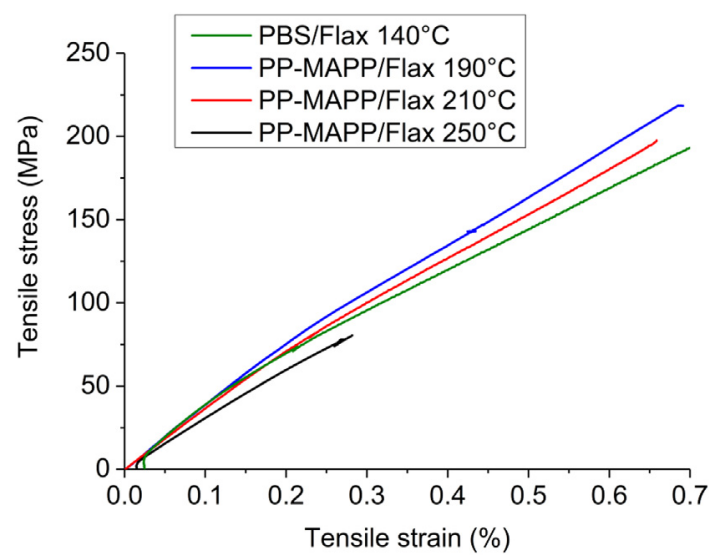

Fig. 6. Tensile stress-strain curves of different composites processed at different temperatures. 

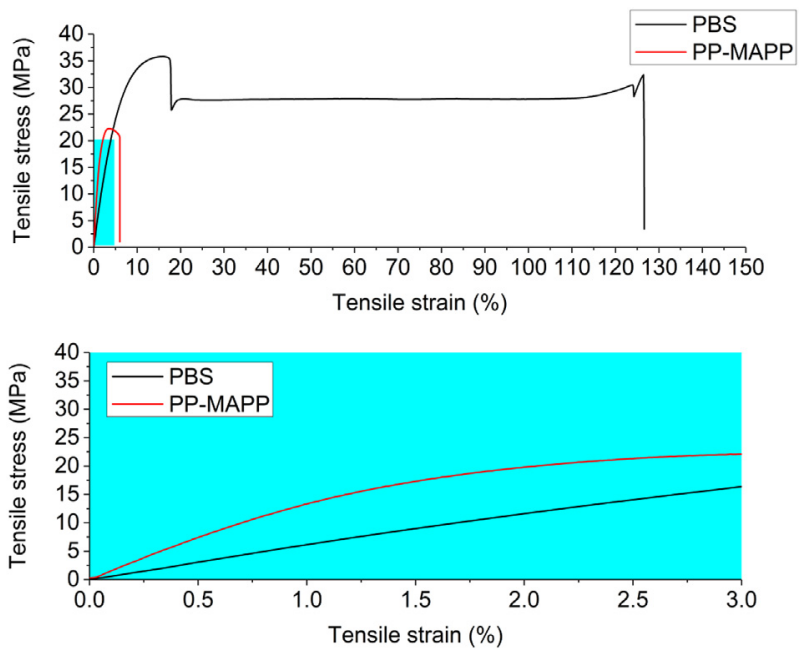

Fig. 7. Tensile stress-strain curves of PP-MAPP and PBS with a zoom of the strain done between 0 and $3 \%$.

\subsection{Tensile tests on UD samples}

While the AFM technique provides local information on fibre stiffness, tensile tests on unidirectional (UD) plies allow for studying the evolution of stiffness and strength at the macroscopic scale. Fig. 6 presents the characteristic stress-strain curves of each UD sample.

UD stress-strain curves exhibit a non-linear pattern typical of biocomposites [29]. In a first approach, the curve can be simply described in terms of two slopes. Plant fibre UD exhibits a Young's modulus change in the first part of the stress-strain curve; indeed, UD plant fibre composites exhibit a large drop of stiffness up to an applied strain of $0.4 \%$, which suggests that the initial stiffness is not an appropriate indicator of the practical stiffness of the composite [9] [36]. Then, in the second part of the curve, the modulus remains relatively stable with a moderate recovery until failure.

After a temperature process at $250{ }^{\circ} \mathrm{C}$, the final elongation is $50 \%$ less than at other temperatures $\left(140{ }^{\circ} \mathrm{C}, 190^{\circ} \mathrm{C}\right.$ and $\left.210{ }^{\circ} \mathrm{C}\right)$. To interpret this behaviour, we need to take into account the properties of the polymers and the quality of the fibre-matrix bond. The tensile behaviour of matrices (PP-MAPP, PBS) is shown in Fig. 7. The PP-MAPP Young's modulus (E), strength $\left(\sigma_{\mathrm{u}}\right)$ and strain at break $(\mathrm{A})$ are $1.55 \mathrm{GPa}$, $22.3 \mathrm{MPa}$ and $6 \%$, respectively. Reciprocally, the properties of PBS are: $\mathrm{E}=0.61 \mathrm{GPa}, \sigma_{\mathrm{u}}=35.8 \mathrm{MPa}$ and $\mathrm{A}=124 \%$. PBS is less stiff and more deformable than PP-MAPP.

To the best of our knowledge, there is no available comparison between PP-MAPP and PBS bonding with flax. Nevertheless, Graupner et al. [37] describe the adhesion between fibres (flax and kenaf) and different matrices: PLA, PP-MAPP and PP. The results of pull-out tests, microbond and fragmentation tests highlight a clear tendency in terms of adhesion. A good adhesion of PLA and PP-MAPP was demonstrated as compared to PP.

Table 1 reports the results of tensile tests on composites. Two tangent Young's moduli (E1 and E2) are indicated (corresponding to two levels of deformation and the two slopes previously described). For PBS/Flax at $140{ }^{\circ} \mathrm{C}$ and PP-MAPP/Flax at $190{ }^{\circ} \mathrm{C}$ and $210{ }^{\circ} \mathrm{C}$, the modulus (E1) is similar but exhibits a strong decrease for PP-MAPP/Flax at $250{ }^{\circ} \mathrm{C}\left(-35.6 \%\right.$ compared to $\left.210{ }^{\circ} \mathrm{C}\right)$. These results are in good agreement with PF-QNM trends (Fig. 5).

The tangent Young's modulus of elementary flax fibres (after thermal treatment) was found to be $51 \mathrm{GPa}, 49.9 \mathrm{GPa}, 46.3 \mathrm{GPa}$ and $30.96 \mathrm{GPa}$ for $140^{\circ} \mathrm{C}, 190^{\circ} \mathrm{C}, 210^{\circ} \mathrm{C}$ and $250^{\circ} \mathrm{C}$, respectively (data from Gourier et al. [6]). The behaviour of isolated single fibres is also nonlinear, and their Young's modulus were measured on the second part of the stress-strain curve (AFNOR NF T 25-501-2). The E2 modulus of the composite was used to study the correlation with fibre stiffness assuming a simple Voigt's mixing rule, taking into account the fibre properties after a thermal cycle [9]. Interestingly, in our case, the estimated stiffness of the UD composites is in the same range as the experimental values (Table 1).

For strength and strain at break measured on the composite samples, optimal values are reached at $190^{\circ} \mathrm{C}$ and a drastic decrease occurs at $250^{\circ} \mathrm{C}$. Fig. 8 shows the fracture surface for two process temperatures. At $140{ }^{\circ} \mathrm{C}$, fibre debonding is visible, whereas, at $250{ }^{\circ} \mathrm{C}$ the composite, especially the fibre fracture surface, appears brittle and almost devoid of debonding with the matrix, confirming the degradation of fibres previously described in PF-QNM on composites. This degradation is not only linked to the loss of water but also the evolution of microstructure and composition as well as interactions between the

Table 1

Results of tensile tests on PBS/Flax $140^{\circ} \mathrm{C}$ and PP-MAPP/Flax processed at $190^{\circ} \mathrm{C}, 210^{\circ} \mathrm{C}$ and $250{ }^{\circ} \mathrm{C}$, with different parameters extracted from the experiments: Young's modulus, strength and strain at break with the associated standard deviation. The estimated UD longitudinal Young's modulus using Voigt's mixing rule is done using data from Fig. 7 for the matrix properties and from Bourmaud et al. [9] for the fibres one.

\begin{tabular}{|c|c|c|c|c|c|}
\hline & $\begin{array}{c}\text { UD } \\
\text { longitudinal } \\
\text { Young's modulus } \\
(\mathrm{GPa}) \\
\mathrm{E}_{1}\end{array}$ & $\begin{array}{c}\text { UD } \\
\text { longitudinal } \\
\text { Young's } \\
\text { modulus } \\
(\mathrm{GPa}) \\
\mathrm{E}_{2}\end{array}$ & $\begin{array}{c}\text { Estimated UD } \\
\text { longitudinal Young's } \\
\text { modulus using Voigt's } \\
\text { mixing rule } \\
(\mathrm{GPa}) \mathrm{E}_{2}\end{array}$ & $\begin{array}{c}\text { UD } \\
\text { strength } \\
\left(\sigma_{u}\right) \\
(\mathrm{MPa})\end{array}$ & $\begin{array}{c}\text { UD } \\
\text { strain at } \\
\text { break (A) } \\
(\%)\end{array}$ \\
\hline $140^{\circ} \mathrm{C}$ & $39.3 \pm 1.0$ & $22.7 \pm 2.9$ & 28.8 & $177 \pm 24$ & $0.67 \pm 0.09$ \\
\hline $190^{\circ} \mathrm{C}$ & $38.8 \pm 4.5$ & $26.7 \pm 2.4$ & 28.1 & $204 \pm 21$ & $0.69 \pm 0.07$ \\
\hline $210^{\circ} \mathrm{C}$ & $36.2 \pm 3.4$ & $25.8 \pm 1.1$ & 28.4 & $180 \pm 10$ & $0.60 \pm 0.06$ \\
\hline $250^{\circ} \mathrm{C}$ & $31.3 \pm 2.9$ & & 18.3 & $63 \pm 15$ & $0.22 \pm 0.06$ \\
\hline
\end{tabular}



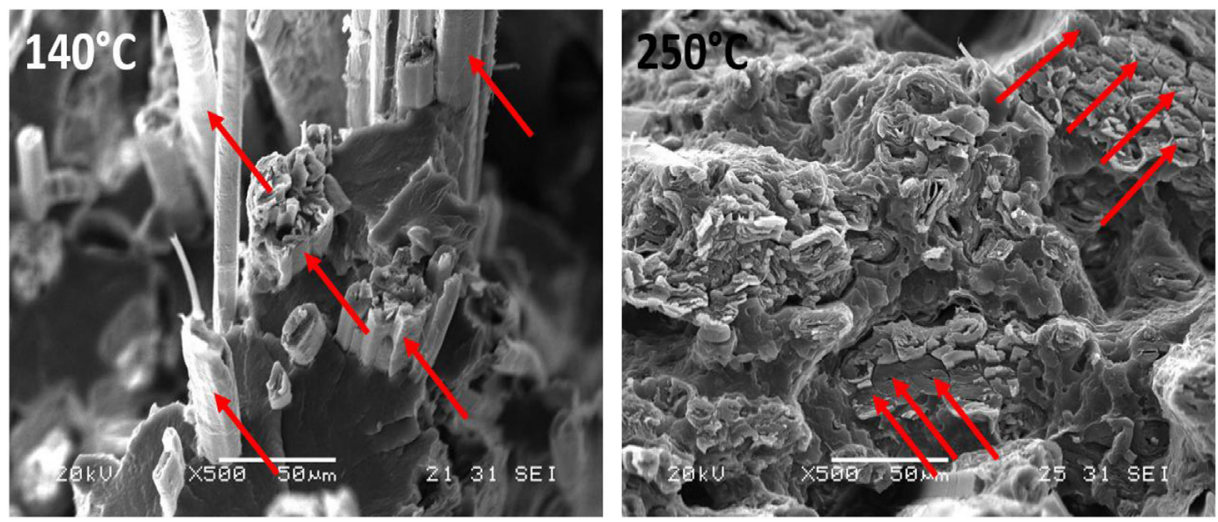

Fig. 8. SEM images of the fracture surface of composites processed at $140^{\circ} \mathrm{C}$ and $250^{\circ} \mathrm{C}$. Red arrows show fibres/matrix debonding at $140{ }^{\circ} \mathrm{C}$ as opposed to $250{ }^{\circ} \mathrm{C}$. (For interpretation of the references to colour in this figure legend, the reader is referred to the Web version of this article.)

constituents, as illustrated by the loss of resistance of elementary fibres (strength at break) with values that fall from 105\% to 35\% [9].

The strength of a ply depends, not only on the properties of the reinforcement, but also on many parameters such as: the quality of interfacial bonding, the volume fraction, the fibre distribution and the presence of defects (e.g., local heterogeneity or porosities). Despite a lower processing temperature $\left(140^{\circ} \mathrm{C}\right)$, the tensile strength of $\mathrm{PBS} / \mathrm{flax}$ is slightly lower than PP-MAPP/flax (Table 1). This result can be explained by the low rigidity of the PBS and its influence on the load transfer between fibres. Usually, the Young's modulus of a composite matrix is around $3 \mathrm{Ga}$ (in the case of epoxy or polyester, for example).

\section{Conclusions}

Use of the PeakForce Quantitative NanoMechanics (PF-QNM) approach is validated for the investigation of submicron-scale elastic behaviour of flax fibres, either isolated or within a composite, allowing a link between macroscale behaviour and process temperature to be established. No indentation modulus gradient can be observed in the flax fibres, irrespective of the temperature process and the boundary conditions of the fibres (isolated or within a composite). The indentation modulus measured by PF-QNM is homogeneous over the whole crosssection of the fibres and decreases for processes at the highest temperature. Above $210^{\circ} \mathrm{C}$, there is a drastic change in the indentation modulus for fibres within the composite, whereas it is quite slight for isolated fibres; this feature highlights the importance of the matrix and fibre confinement effect on mechanical properties. The mechanical properties of fibres within a matrix, as revealed by PF-QNM, are constant up to $190^{\circ} \mathrm{C}$, followed by a drastic loss of indentation modulus at higher temperature. An embrittlement of the UD and fibres occurs with increasing temperature of the process.

\section{Acknowledgements}

The authors thank Helmut Gneagi (Diatome, Switzerland) and Myriam Collin (IRD Montpellier, France) for their help in sample preparation and Mickael Febrve (Brucker, France) for fruitful discussions. They are also grateful to Fiabilin, Oseo, Region Bretagne and CNRS for funding this work. Michael Carpenter post-edited the English style and grammar.

\section{References}

[1] C. Baley, Analysis of the flax fibres tensile behaviour and analysis of the tensile stiffness increase, Compos. Part A - Appl. Sci. Manuf 33 (2002) 939-948 https:// doi.org/10.1016/S1359-835X(02)00040-4.

[2] A. Bourmaud, C. Baley, Effects of thermo mechanical processing on the mechanical properties of biocomposite flax fibers evaluated by nanoindentation, Polym. Degrad. Stabil. 95 (2010) 1488-1494 https://doi.org/10.1016/j.polymdegradstab.
2010.06.022.

[3] A. Lefeuvre, A. Bourmaud, C. Morvan, C. Baley, Tensile properties of elementary fibres of flax and glass: analysis of reproducibility and scattering, Mater. Lett. 130 (2014) 289-291 https://doi.org/10.1016/j.matlet.2014.05.115.

[4] A. Le Duigou, P. Davies, C. Baley, Interfacial bonding of Flax fibre/Poly(l-lactide) bio-composites, Compos. Sci. Technol. 70 (2010) 231-239 https://doi.org/10. 1016/j.compscitech.2009.10.009.

[5] K. Van de Velde, E. Baetens, Thermal and mechanical properties of flax fibres as potential composite reinforcement, Macromol. Mater. Eng. 286 (2001) 342-349 https://doi.org/10.1002/1439-2054(20010601)286:6\%3c342 (AIDMAME342 > 3.0.CO;2-P).

[6] C. Gourier, A. Le Duigou, A. Bourmaud, C. Baley, Mechanical analysis of elementary flax fibre tensile properties after different thermal cycles, Compos. Part Appl. Sci. Manuf 64 (2014) 159-166 https://doi.org/10.1016/j.compositesa.2014.05.006.

[7] C. Baley, A. Le Duigou, A. Bourmaud, P. Davies, Influence of drying on the mechanical behaviour of flax fibres and their unidirectional composites, Compos. Part A - Appl. Sci. Manuf 43 (2012), https://doi.org/10.1016/j.compositesa.2012.03. 005.

[8] V. Placet, Characterization of the thermo-mechanical behaviour of Hemp fibres intended for the manufacturing of high performance composites, Compos. Part A Appl. Sci. Manuf 40 (2009) 1111-1118 https://doi.org/10.1016/j.compositesa. 2009.04.031.

[9] A. Bourmaud, A. Le Duigou, C. Gourier, C. Baley, Influence of processing temperature on mechanical performance of unidirectional polyamide 11-flax fibre composites, Ind. Crop. Prod. 84 (2016) 151-165 https://doi.org/10.1016/j. indcrop.2016.02.007.

[10] M. Eder, O. Arnould, J.W.C. Dunlop, J. Hornatowska, L. Salmén, Experimental micromechanical characterisation of wood cell walls, Wood Sci. Technol. 47 (2013) 163-182 https://doi.org/10.1007/s00226-012-0515-6.

[11] Y. Li, L. Yin, C. Huang, Y. Meng, F. Fu, S. Wang, Q. Wu, Quasi-static and dynamic nanoindentation to determine the influence of thermal treatment on the mechanical properties of bamboo cell walls, Holzforschung 69 (2015), https://doi.org/10. 1515/hf-2014-0112.

[12] G. Zickler, T. Schoberl, O. Paris, Mechanical properties of pyrolysed wood: a nanoindentation study, Philos. Mag. A 86 (2006) 1373-1386 https://doi.org/10. 1080/14786430500431390.

[13] S. Stanzl-Tschegg, W. Beikircher, D. Loidl, Comparison of mechanical properties of thermally modified wood at growth ring and cell wall level by means of instrumented indentation tests, Holzforschung 63 (2009) 443-448 https://doi.org/ 10.1515/HF.2009.085.

[14] Y. Yin, L. Berglund, L. Salmén, Effect of steam treatment on the properties of wood cell walls, Biomacromolecules 12 (2011) 194-202 https://doi.org/10.1021/ bm $101144 \mathrm{~m}$.

[15] G. Coroller, A. Lefeuvre, A. Le Duigou, A. Bourmaud, G. Ausias, T. Gaudry, C. Baley, Effect of flax fibres individualisation on tensile failure of flax/epoxy unidirectional composite, Compos. Part Appl. Sci. Manuf 51 (2013) 62-70 https://doi.org/10. 1016/j.compositesa.2013.03.018.

[16] B. Pittenger, N. Erina, S. Chanmin, Quantitative mechanical mapping at nanoscale with peak force QNM, Bruker Appl. Note (2009).

[17] D. Ren, Z. Yu, X. Zhang, H. Wang, H. Wang, Y. Yu, Quantitative characterization of the interface between bamboo fiber and polypropylene with pull-out test and nanomechanical imaging, J. Mater. Sci. 52 (2017) 1296-1307 https://doi.org/10. 1007/s10853-016-0425-3.

[18] O. Arnould, D. Siniscalco, A. Bourmaud, A. Le Duigou, C. Baley, Better insight into the nano-mechanical properties of flax fibre cell walls, Ind. Crops and products 97 (2017) 224-228 https://doi.org/10.1016/j.indcrop.2016.12.020.

[19] F. Bert, Lin Fibre: culture et transformation, Arvalis 88 (2013).

[20] M. Shibata, Y. Inoue, M. Miyoshi, Mechanical properties, morphology, and crystallization behavior of blends of poly(l-lactide) with poly(butylene succinate-co-1lactate) and poly(butylene succinate), Polymer 47 (2006) 3557-3564 https://doi. org/10.1016/j.polymer.2006.03.065.

[21] A.J. Nuñez, N.E. Marcovich, M.I. Aranguren, Analysis of the creep behavior of 
polypropylene-woodflour composites: creep Behavior of PP-Woodflour Composites, Polym. Eng. Sci. 44 (2004) 1594-1603 https://doi.org/10.1002/pen.20157.

[22] H. Jeske, A. Schirp, F. Cornelius, Development of a thermogravimetric analysis (TGA) method for quantitative analysis of wood flour and polypropylene in wood plastic composites (WPC), Thermochim. Acta 543 (2012) 165-171 https://doi.org/ 10.1016/j.tca.2012.05.016.

[23] G. Dorez, A. Taguet, L. Ferry, J.M. Lopez-Cuesta, Thermal and fire behavior of natural fibers/PBS biocomposites, Polym. Degrad. Stabil. 98 (2013) 87-95 https:// http://dx.doi.org/10.1016/j.polymdegradstab.2012.10.026.

[24] S.T. Jespersen, M.D. Wakeman, V. Michaud, D. Cramer, J.-A.E. Månson, Film stacking impregnation model for a novel net shape thermoplastic composite preforming process, Compos. Sci. Technol. 68 (2008) 1822-1830 https://doi.org/10. 1016/j.compscitech.2008.01.019.

[25] O.A. Khondker, U.S. Ishiaku, A. Nakai, H. Hamada, Fabrication mechanical properties of unidirectional Jute/PP composites using Jute Yarns by film stacking method, J. Polym. Environ. 13 (2005) 115-126 https://doi.org/10.1007/s10924005-2943-y.

[26] P. Ouagne, L. Bizet, C. Baley, J. Breard, Analysis of the film-stacking processing parameters for PLLA/flax fiber biocomposites, J. Compos. Mater. 44 (2010) 1201-1215 https://doi.org/10.1177/0021998309349019.

[27] J.E. Sader, J.A. Sanelli, B.D. Adamson, J.P. Monty, X. Wei, S.A. Crawford, J.R. Friend, I. Marusic, P. Mulvaney, E.J. Bieske, Spring constant calibration of atomic force microscope cantilevers of arbitrary shape, Rev. Sci. Instrum. 83 (2012) 103705 https://doi.org/10.1063/1.4757398.

[28] E. Barthel, Adhesive elastic contacts: JKR and more, J. Phys. Appl. Phys. 41 (2008) 163001 https://doi.org/10.1088/0022-3727/41/16/163001.

[29] A. Bourmaud, D. Akesson, J. Beaugrand, A. Le Duigou, M. Skrifvars, C. Baley, Recycling of L-Poly-(lactide)-Poly-(butylene-succinate)-flax biocomposite, Polym.
Degrad. Stabil. 128 (2016) 77-88 https://doi.org/10.1016/j.polymdegradstab. 2016.03.018.

[30] O. Paris, C. Zollfrank, G.A. Zickler, Decomposition and carbonisation of wood biopolymers-a microstructural study of softwood pyrolysis, Carbon 43 (2005) 53-66 https://doi.org/10.1016/j.carbon.2004.08.034.

[31] C. Zollfrank, J. Fromm, Ultrastructural development of the softwood cell wall during pyrolysis, Holzforschung 63 (2009) 248-253 https://doi.org/10.1515/HF. 2009.031.

[32] C. Baley, C. Morvan, Y. Grohens, Influence of the absorbed water on the tensile strength of flax fibers, Macromol. Symp. 222 (2005) 195-202 https://doi.org/10. 1016/j.compositesa.2005.10.014.

[33] B. Brandt, C. Zollfrank, O. Franke, J. Fromm, M. Göken, K. Durst, Micromechanics and ultrastructure of pyrolysed softwood cell walls, Acta Biomater. 6 (2010) 4345-4351 https://doi.org/10.1016/j.actbio.2010.05.026.

[34] A. Stamboulis, C.A. Baillie, T. Peijs, Effects of environmental conditions on mechanical and physical properties of flax fibers, Compos. Part A - Appl. Sci. Manuf 32 (2001) 1105-1115 https://doi.org/10.1016/S1359-835X(01)00032-X.

[35] G. Agarwal, G. Reyes, P. Mallick, Study of compressibility and resin flow in the development of thermoplastic matrix composite laminates by film stacking technique, Manuf. Compos., ASC Series (2013) 215-227 https://doi.org/10.1021/ jf304465k.

[36] D.U. Shah, Damage in biocomposites: stiffness evolution of aligned plant fibre composites during monotonic and cyclic fatigue loading, Compos. Part A - Appl. Sci. Manuf 83 (2016) 160-168 https://doi.org/10.1016/j.compositesa.2015.09.008.

[37] N. Graupner, J. Rößler, G. Ziegmann, J. Müssig, Fibre/matrix adhesion of cellulose fibres in PLA, PP and MAPP: a critical review of pull-out test, microbond test and single fibre fragmentation test results, Compos. Part A - Appl. Sci. Manuf 63 (2014) 133-148 https://doi.org/10.1016/j.compositesa.2014.04.011. 